www.pasosonline.org

\title{
From church perseverance in authoritarian states to today's religious inspired tourism
}

\author{
Vítor Ambrósio* \\ Escola Superior de Hotelaria e Turismo do Estoril (Portugal) \\ Carlos Fernandes** \\ Instituto Politécnico de Viana do Castelo (Portugal) \\ Alfred Krogmann*** \\ Constantine the Philosopher University in Nitra (Eslovakia) \\ Isilda Leitão***** \\ Escola Superior de Hotelaria e Turismo do Estoril (Portugal) \\ Daša Oremusová****** Lucia Šolcová*******
Constantine the Philosopher University in Nitra (Eslovakia)
}

\begin{abstract}
A chronological analysis of Christian pilgrimages over the course of around 2,000 years of existence suggests that there have been swings in their level of popularity: strong whenever the ruling classes (whether religious or civil) protect popular sanctuaries and declining whenever policies constraint the practice of pilgrimages. This paper starts with the characterization of two authoritarian regimes, a fascist one in a western European country, Portugal (1928-1974), and a communist one in a central European country, Slovakia (1948-1989), at that time part of Czechoslovakia. The aim of this research was to explore the status quo during the period of government by the two authoritarian regimes, analyse the approach taken by each regime in regards to religious manifestations and how, with the eventual transition to democracy, it served to determine the dynamics surrounding each country's main pilgrimage shrine, respectively Fatima (Portugal) and Levoča (Slovakia). The research findings show that in Portugal there was no interruption on the increasing popularity and development of Fatima, from the authoritarian to democratic regimes. Meanwhile, in Slovakia only after democracy was reinstated, was it allowed for people to manifest freely their religious beliefs that led to a revival of pilgrimages and visits to Levoča. The findings provide an understanding of the role of the state under authoritarian regimes and the policies implemented that prompted the importance and potential of the two shrines as religious tourism destinations.
\end{abstract}

Keywords: Authoritarian; Democratic; Regimes; Pilgrimage; Religion and tourism.

\footnotetext{
* Escola Superior de Hotelaria e Turismo do Estoril (Portugal); E-mail: vitor.ambrosio@eshte.pt

* Instituto Politécnico de Viana do Castelo (Portugal); E-mail: cfernandes@estg.ipvc.pt

*** Constantine the Philosopher University in Nitra (Eslovakia); E-mail: akrogmann@ukf.sk

**** Escola Superior de Hotelaria e Turismo do Estoril (Portugal); E-mail: isilda.leitao@eshte.pt

***** Constantine the Philosopher University in Nitra (Eslovakia); E-mail: doremusova@ukf.sk

****** Constantine the Philosopher University in Nitra (Eslovakia); E-mail: lsolcova@ukf.sk
} 


\section{Desde la perseverancia de la iglesia en estados autoritarios hasta el turismo de inspiración religiosa de hoy}

Resumen: Un análisis cronológico de las peregrinaciones cristianas a lo largo de 2,000 años de existencia sugiere que ha habido cambios en su nivel de popularidad: fuerte, siempre que las clases dominantes (ya sean religiosas o civiles) protegen los santuarios populares, y débil, cada vez que las políticas restringen la práctica de las peregrinaciones. Este trabajo comienza con la caracterización de dos regímenes autoritarios, uno fascista en un país de Europa occidental, Portugal (1928-1974), y uno comunista, en un país del centro de Europa, Eslovaquia (1948-1989), en ese momento parte de Checoslovaquia. El objetivo de esta investigación fue explorar el status quo durante el período de gobierno de los dos regímenes autoritarios, analizar el enfoque adoptado por cada régimen con respecto a las manifestaciones religiosas y cómo, con la eventual transición a la democracia, sirvió para determinar la dinámica que encierra el santuario de peregrinación de cada país, Fátima (Portugal) y Levoča (Eslovaquia) respectivamente. Los resultados de la investigación muestran que en Portugal no hubo interrupción en la creciente popularidad y desarrollo de Fátima, desde los regímenes autoritarios hasta los democráticos. Mientras tanto, en Eslovaquia solo después de la reinstauración de la democracia, se permitió a las personas manifestar libremente sus creencias religiosas, lo que condujo a un renacimiento de las peregrinaciones y visitas a Levoča. Los resultados proporcionan una comprensión del papel del estado bajo regímenes autoritarios y las políticas implementadas que impulsaron la importancia y el potencial de los dos santuarios como destinos turísticos religiosos.

Palabras Clave: Autoritario; Democrático; Regímenes; Peregrinación; Religión y turismo.

\section{Introduction}

In the last three centuries of the European History, there are strong examples of persecution such as the Enlightenment (18th cent.), the French Revolution and its spread to the rest of the continent. These campaigns encouraged persecution and, frequently, the destruction of the holy places of greatest significance to worshippers (19th cent.) or the Communist Dictatorships in Eastern Europe (20th cent.) which discouraged religious practices. Nevertheless, during these same years, the exaltation of worship of the Virgin was reinforced (18th Century), within the scope of Romanticism, pilgrimages were associated with people's hidden soul (19 ${ }^{\text {th }}$ Century) and the organization of pilgrimages boomed, sometimes supported and stimulated by authoritarian regimes in southern European countries ( $20^{\text {th }}$ Century). European society changed rapidly, particularly in terms of religious demographics (Cipriani, 2009) and for most of the $20^{\text {th }}$ century, all Western European societies underwent secularization (Northmore-Ball and Evans, 2016).

Because religion has manifold and differing functions for different societies, these functions underlie and influence the relationships between religious institutions and the state (Robbers, 2001). Catholicism is a widely spread religion in Europe, representing the primary religious influence in central and southern areas but with significant differences within different countries. This study explores practices of authoritarian regimes and the relationship with the Church and the religious environment to help understand the current positioning of two Marian shrines and main pilgrimage sites in Portugal and Slovakia, Fatima and Levoča respectively. How communist and fascist ideologies impacted the fundamental values of the Catholic Church, particularly during the 20th century in Portugal and Slovakia and how it influenced the shaping of current trends in religiosity (belief, practices and behavior). In both countries, the state sought suppression of religious expression adopting two different approaches: one in which the state tolerated religious practices and behavior as long as it was favorable to the state (Portugal) and the other through the suppression of religion altogether (Slovakia).

\section{Church and State - relationship and key characteristics}

Churches constitute an important instance of civil society. They provide opportunities for citizens to gather on a regular basis, to discuss public issues, and to develop relationships that enable them to solve community problems (Smith, 2017). Most theories of religion assume that religion nourishes such prosocial behavior (Norenzayan and Shariff, 2008) that often leads to social mobilization where major clusters of old social, economic and psychological commitments are eroded or broken and people become available for new patterns of socialization and behavior (Deutsch, 1961). As social contact is frequent, the tendency is a fundamental shift in values, attitudes and expectations by those who share a social identity and tend to induce each other into pursuing civic activities. Changes in the aspirations of individuals, 
groups and societies become more evident (Huntington, 1968), particularly amongst economic insecure and vulnerable populations such as the uneducated, the poor, the old and those in low status occupations (Northmore-Ball and Evans, 2016) in the search for meaning in their lives. The Catholic Church is very effective with its communication with the believers, particularly the sick, the poor and the fragile, be it through images, gestures or simple language that is easy to follow and understand (da Mota, 2017).

People who have been persuaded can, in turn, become opinion leaders, more rapidly converting the entire group (Wald et al, 1988). The tendency is to think that because social modernization is taking place, political modernization also must be taking place (Huntington, 1968). However, authoritarian states perceive this prosocial behavior as turning church doctrine into sharp conflict with political regimes and ideology and thus potentially de-legitimizing it (Cosgel and Miceli, 2009), requiring the destruction or weakening of the traditional institutions, like the Church. Authoritarian leaders strike a bargain with their citizens, but offer no explanation-cultural, social or political, of why legitimacy is decisive for authoritarian survival (Grigordiadis, 2016).

Throughout history, states have had an uneasy relationship with religion. At times, rulers have controlled the religious practices, at other times have treated religion as independent of the state, and at still other times have suppressed it altogether. Authoritarian systems model the state as the dominant player with the ability to run or suppress religion depending on how the latter is expected to affect the state's interests (Cosgel and Miceli, 2009). Two such authoritarian systems are fascism (right wing) and communism (left wing).

Paxton (2004: 218) defines fascism as "a form of political behavior marked by obsessive preoccupation with community decline, humiliation, or victim-hood and by compensatory cults of unity, energy, and purity, in which a mass-based party of committed nationalist militants, working in uneasy but effective collaboration with traditional elite groups, abandons democratic liberties and pursues with redemptive violence and without ethical or legal restraints goals of internal cleansing and external expansion". For Payne (1995: 14), "fascism may be defined as a form of revolutionary ultra-nationalism for national rebirth that is based on a primarily vitalist philosophy, is structured on extreme elitism, mass mobilization, and the Fuhrerprinzip, positively values violence as end as well as means and tends to normalize war and/or the military virtues". Fascist systems attempt to dominate and control non-state institutions, espouse limited worldviews, reject socialism and embrace capitalism.

On the other side of the spectrum, communism is a system of social organization in which government owns most productive assets of the society-private property in the means of production is not the general rule-and government immediately and directly organizes the economy. But it reaches as well into the control of religion, all education, family, labor unions, all organizations, and details of personal behavior usually outside the scope of government in other systems (Lindbloom, 1977) and where citizens receive according to their ability and needs.

Huntington (1968) argues that if the function of government is to govern then communist governments do provide effective authority; they do govern. Their ideology furnishes a basis of legitimacy and their party organization provides the institutional mechanism for mobilizing support and executing policy. They may not provide liberty but they do provide authority; they do create governments that can govern and provide political order. The communism system largely refuses to its citizens the civil liberties: freedom of thought, speech, religion, assembly and movement, as well as privacy.

It is common knowledge that the communist ideology was against any form of religious manifestation; and, communism itself was attempting to become some sort of religion for its followers. Communist ideology as in itself an attempt to become the only religion assumed, accepted and practiced by the entire people....in order to impose themselves, ideology had to become a dogma for the citizens and, thus, become a substitute for any other beliefs (Necula, 2012).

The combination of remorseless centralism, coupled with the violent shattering of the way of life of a significant part of the population and the destruction of almost every remnant of the population's independent associative life, meant that the regime saw in every sign of communal autonomy and resistance an indication of conspiracy and breakdown (Unger, 1987) that dictated the intensity of state repression (Northmore-Ball and Evans, 2016).

But the Church was able to resist state repression under both authoritarian systems. By having a significant portion of the Church institutions beyond the reach of the authoritarian systems, its numerous religious and lay educational institutions which operate all over Europe, especially in countries with a strong Catholic presence, the Catholic Church could not be delegitimized (Cipriani, 2009; Northmore-Ball and Evans, 2016). Huntington (1991) dubbed the third wave of democratization the "Catholic wave of democratization" highlighting the crucial role of the Catholic Church in bringing down authoritarian regimes. Linz and Stepan (1996) go so far as to argue that a totalitarian regime 
is impossible in a society where the Catholic Church has a strong presence historically, because it is a constant source of "latent pluralism". In the appeal to believers, to pray in order to bring about a feeling of inspiration and hope, sermons and speeches represent a psychological factor and energy-building psyche. When people lose hope, they tend to turn to religion for guidance.

\section{Methodology}

Under a research project of a cooperation agreement between the national research foundations of Portugal and Slovakia, researchers from each country exchanged visits to Fatima and Levoča during the anniversary celebrations - 12th/13th of May in Fatima and the first weekend of July in Levoča - to observe, compare and discuss the religious site dynamics at the two Marian shrines. To understand the two shrines, we must first appreciate the reasoning behind the Marian orientation. A universal symbol of maternal love, as well as of suffering and sacrifice, Mary is often the touchstone of our longing for meaning, a more accessible link to the supernatural than the formal church teachings. Her reported appearances, visions experienced often by very poor children living in remote or conflict-wracked areas, have intensified her mystery and aura [case of Fatima or Lourdes]. Moreover, when the children can't be shaken from their stories, her wonder grows. Mary draws millions each year to shrines such as Fatima, Lourdes or Guadalupe, sustaining religious tourism estimated to be worth billions of dollars a year and providing thousands of jobs (Orth, 2015).

Despite religious tourism and pilgrimage having gained prominence in recent years, as evidenced by the increasing visitor numbers to sites and of pilgrims on the Ways, there is still a general need for increased knowledge on his phenomenon. It is difficult to manage something you cannot measure (Heide \& Gronhaug, 2006). Measurement instruments need to be developed to enable planners and hospitality managers to assess the needs for future development.

But this study is about understanding how two locations in Europe evolved through time, particularly during authoritarian regimes, to become iconic religious and pilgrimage sites. Almost no statistical data is available on the visitor numbers or local stakeholders. As such, this research is mainly of a descriptive nature, based on qualitative methods. Research duties were distributed amongst the researchers based on their particular expertise, with a focus on the literature review, to describe, analyse and explore the reaction of states to religious manifestations at a time of authoritarian political-philosophical era in $20^{\text {th }}$ century Europe and what policies were implemented regarding religious practices and the inclination towards local development.

The literature review was supplemented by fieldwork carried out by all researchers essentially in the form of observation. While some of the researchers concentrated on the literature review, others supplemented this technique with the gathering of data by observation at the two religious sites, and by consulting information from local sources, such as regional and national press. The assimilation of the data gathered led to a discussion and reflection of the findings to improve our understanding of the position that Fatima and Levoča occupy today as religious tourism and pilgrimage destinations.

\section{Authoritarian States: The background}

\section{Portuguese Fascist Dictatorship}

After the Great War (1914-1918), a new cycle opened in the history of the world, preparing the ground for authoritarian, repressive and xenophobic regimes, notably in Italy (1922), Japan (1931) and Germany (1933), three powers linked by various treaties since the 1930s (Leitão, 2004). Similarly, in Portugal, secular counterrevolutionary thought of the late $19^{\text {th }}$ and early $20^{\text {th }}$ centuries, inspired by doctrines of reaction to liberalism spurred a spirit of social Catholicism and some of the forms of republican-conservative ideology (Portugal implemented its first Republic in 1910). This movement served as a basis for the Salazarist dictatorship (1926-1968) and later, Marcelist dictatorship (1968-1974) towards the creation of the "New Man".

Salazar's corporatist Estado Novo (New State), imposed on Portugal, in 1933 after six years of an "interim" dictatorial military regime, institutionalized a social order dominated by an agricultural and a small industrial aristocracy whose economic power was highly concentrated and centralized. The Estado Novo lasted until Democratic Revolution of the 25th of April, in 1974. This dictatorial machine exercised negatively a prior censorship with the cultural media, often supported by citizens informing the Republican National Guard or the much feared and repressive police force of the dictatorship called the International Police for the Defense of the State (widely known as simply PIDE). 
According to Rosas (1998) the focus of this ideology was structured around certain ideological myths, starting with the expression "Everything for the Nation, nothing against the Nation". One would be considered a traitor if dared to question this state model. Furthermore, Portugal was, for Salazarism, in its essence a rural country. It was in the countryside, in the homeland, that the true virtues of the race were found. This rural vocation of the Nation thus emerged as a way of escaping industrialization, with the consequent burden of social proletarianization, which the Estado Novo feared.

Another myth was that of the honorable poverty (in fact most Portuguese were at the time very poor), or myth of the golden mediocrities, the accommodation of each one to his destiny of poverty, would lead the Portuguese people to live the paradigm of possible happiness. We know the famous slogan of the time, about poverty "poor, but honest". Then there was the expression of the natural order of things. The Estado Novo constructed the idea of a "spontaneous and harmoniously accepted social hierarchy in the framework of an organic society," in which there would be "a place for each and every one in its place", that is, it helped to reveal "another vocation of the Portuguese essentiality: a vocation of order, hierarchy and acceptance of the resulting natural authority".

This essence had to do with rural people seeing themselves as more powerless than they really were, in what Lerner (1986) calls "surplus powerlessness". Freire (1972) also wrote of the "culture of silence" and said that the rural poor have "no voice, no access and no participation". People feel powerless because their problems are complex and require knowledge they often lack. Consequently, when a priest preaches about duty and salvation of the people, about finding peace through sacrifice in regards to pilgrimages and the use of symbols and religious heritage in the transmission of different values he is expressing the "natural hierarchy" of the community led by the Church. The symbolism of the faithful followers in a procession, as the religious leader goes at the front and the saints carried on (heavy) wooden structures on the shoulders of the faithful (Image 1) in which looking up symbolizes a sign of respect and acceptance of authority.

Image 1: Saint carried by the faithful

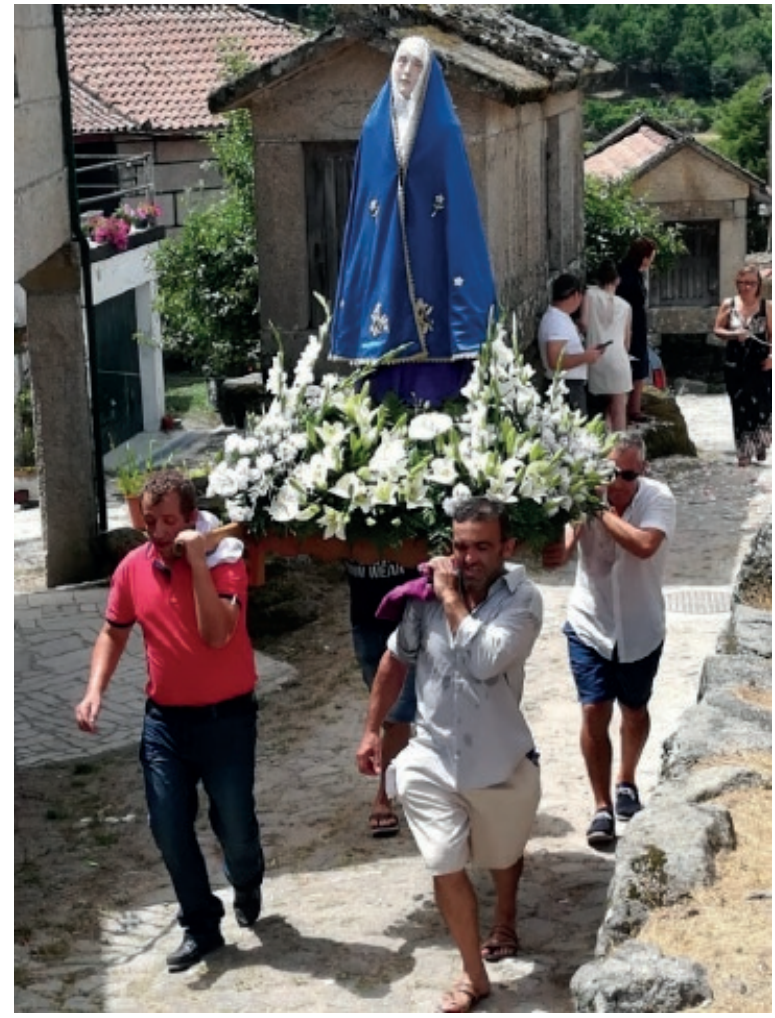

Source: Authors 
Finally, the myth of the Catholic essence of national identity, which understood "the Catholic religion as a constituent element of the Portuguese being, as a defining attribute of one's own nationality and its history" as "a religious, Christian and Catholic vocation of the Portuguese nation".

It is understandable Salazar's interest in separating the Church from the State, eluding intervention, in line with the republican tradition. They used religion as a way of dominating the Corporate State and the uneven social classes it had created. Although in a similar way to the Spanish dictatorship of Francisco Franco (1939-1975), in Portugal, however, the relationship between Church and State managed to facilitate the celebration of a "discursive and moral alliance" that united the two institutions, a Portuguese-style "national-Catholicism" (Simpson, 2014).

"The discourse of the respective leaders of the Portuguese Catholic Church and the Salazarist state shared practically the same interpretation of the essence and mission of Portugal as a nation. The program of "national revolution" delineated by Salazar on May 26 of 1936 (God, Fatherland, Authority, Family, Labor), was hailed as "truly Portuguese, Christian and national". Catholicism was therefore the primary cause of the nation's historical development and the ultimate reason for his glorious deeds. The presence of prominent ecclesiastical figures alongside representatives of the state quickly became an indispensable feature of the official ceremony that accompanied the consolidation of the regime. The ecclesiastical hierarchy was also associated with the celebratory rituals destined to celebrate the era of "National redemption" inaugurated by the military dictatorship and, in political terms, served to consolidate the legitimacy of the Salazar regime (Simpson, 2014).

During this period, the few critical voices that stood in the bosom of the Catholic Church would be phased out. Catholicism passes through education, dismantling the secular legislation created by the Republic. Manuals are created, especially at the primary level, to instill religious and nationalist sentiment, and teachers are evaluated by parish priests. Public education, through the "constitutional revision of 1935," becomes formally subjected to "the principles of moral and Christian doctrine" (Simpson, 2014). In 1940, an accord was signed between the State and the Catholic Church still valid today. The Concordat between the Holy See and the Portuguese Republic states in article 2 (Ecclesia, 2004) "The Catholic Church is guaranteed the free exercise of its authority: in the sphere of its competence, it has the power to exercise the acts of its power of order and jurisdiction without any impediment."

Portuguese fascism, exercising active censorship and strong police repression, relied on the "Christianization of laws and institutions". As an example, the fact that Portugal did not enter World War II was seen as the Church associating the figure of Salazar with Portugal's providential history, with the "Portuguese miracle of peace". The great pilgrimages to Fatima, like those of 1946 and 1951, already in the context of the Cold War and the "communist threat", demonstrated the "continued commitment of the Church to a triumphalist approach", turning evident the "mass mobilization strategy of the faithful through pilgrimages and processions, in a close association with the political authorities (Simpson, 2014).

The Salazarist and Marcelist dictatorial period (1926-1974) ended with the Revolution of the $25^{\text {th }}$ of April of 1974, instituting a New Republic, whose "new democratic mythology" is the 3 D's - Develop, Decolonize, Democratize. For Simpson (2014: 245), "this posture, combined with the conciliatory attitude of the "revolutionaries", proved sufficient to spare the Catholic Church any serious political reprisal and even to allow (the Church) to evade an examination of conscience for the role it played in the dictatorial era.

\section{Czechoslovakian Communist Dictatorship}

After the World War II, geopolitical orientation of renewed Czechoslovakia towards the Soviet Union changed, as confirmed by the 1943 Czechoslovakian and Soviet agreement (Renner and Samson, 1993). The orientation towards the Soviet Union can be justified by the fact that after the defeat of Germany, it was possible to expect stronger influence of the Soviet Union in Central Europe. Moreover, most of the territory of Czechoslovakia was liberated by the Red Army troops and people still were not over the trauma of the ultimatum of the Munich "experience" of the Sudeten Crisis of 1938. Here, representatives of France, Britain, Italy and Germany met at Munich, without the presence of representatives of Czechoslovakia and agreed to let Germany annex strategically important border regions of Czechoslovakia, in exchange for a promise of peace in Europe. The Czechs had to either accept or face the powerful German army by itself. This decision became known as the policy of appeasement followed by Britain and France. But as history shows, Germany would continue to behave aggressively and war became inevitable.

In the first post-war elections in May 1946, the Communists won and with the support of the Social Democrats obtained a majority in Parliament. The Chairman of the Communist Party of Czechoslovakia, Klement Gottwald, became the Prime Minister. Communists gained influence in power institutions 
as well as in labor organizations. In February 1948, there was a government crisis during which the Communists exerted strong pressure on the President to accept the resignation of the ministers from the democratic parties. Ultimately, a new government was formed in which the Communist Party dominated. Through this move, Czechoslovakia was pulled into the Soviet block of power. The pluralist system in the country was systematically destroyed and any opposition opinion was punished.

After the taking of power, the church was marked by the leaders of the Communist Party as the last and most dangerous enemy (Dubovský, 1998). The Communist political atheists looked at the Church as a political power, which prevented them from realizing their goals, which implied its plan of constant control (Hal'ko, 2012). One of the first actions taken was the abolition of church schools.

In April 1949, the Presidency of the Communist Party approved a new line of Church policy. It contained two basic tasks. The first was to organize the so-called revival movements of Catholics and to create national Catholic Church, which will be detached from Vatican and loyal to the young totalitarian system in Czechoslovakia. According to Halko (2004), the rupture with Vatican and movement of believers against the bishops was to be provoked by the "Catholic Action" - a "revival" Catholic movement that was declared a schismatic movement by the Pope Pius XII in June 1949 who also excommunicated all who conspicuously joined or will later join this movement.

The second task was to approve administrative measures to control and expel the Church from public life. Government officials were appointed to join the bishops' offices since June 1949 in order to control its work as well as the bishops themselves and their colleagues. This practice was only abolished in April 1968 (Petruf and Sikora, 2007). Having failed to divide the Church from within, the Communist leadership took actions in the field of legislation to make the churches completely subordinate to the state. By the Act no. 217/1949, the State Office for Church Affairs was created (Pešek, 2000). It was an office where the church did not have any influence on the composition of its staff and it was therefore an executor of the state's restrictive policy towards the churches.

By the Act no. 218/1949 (without any significant changes until the fall of the Communist regime), the State undertook to provide all Church staff with a salary on the condition of State approval which could only be granted to the state citizens with acknowledged credibility and integrity. In return for the authorization for the Church to perform the spiritual and preaching activities, the State expected the promise of loyalty to the District and County Party chairpersons or alternatively the Prime Minister, depending on the matter. The approval of Church laws and government regulations had far-reaching consequences for religious life in Czechoslovakia. The churches lost the classification of a legal entity under public law. The State managed to infiltrate into the structure of the church and fully controlled its financial and personnel policies. Such legislation fully complied with the Communist regime and its policies and remained practically intact until 1990.

The 1950s and early 1960s were characterized by the persecutions of almost all of the society classes and by the fabricated judicial processes. Intimidation, propaganda campaigns and repression were common practice. Overall, 250 people were executed for the so-called anti-state actions, up to 500 people perished at the border when trying to escape, nearly 600 people were murdered by the state security agency during hearings, and over 8000 prisoners perished in mines or prisons. Many victims of the regime were imprisoned without trial in labor camps, in technical assistance battalions, and together with their family members, they were denied access to education (Mikloško, 2009).

The regime continued very attentive to the Catholic Church. In 1951, the Communist initiative established a Peace Movement of the Catholic Church with the purpose of promoting the idea of building a new establishment with the participation of the priests. Priests who refused were persecuted. Steps were taken to weaken the influence of the bishops and to break the unity between priests and bishops as well as weaken the influence and authority of the Holy Trinity. The Communists thought that by engaging the priests in the peace movement they would neglect their pastoral activity. The effort to eliminate the Catholic Church further led to the destruction of the Orders, abolished in 1950. In the same year, more than 300000 Greek Catholics united with Rome were obliged to convert to the Orthodox Church, subjugated to the Moscow Patriarchate. The attacks on the Catholic Church culminated with the imprisonment of four bishops, sentenced to between 24 years and life incarceration.

The 1960s brought a slight relief, exacerbated by the so-called Prague Spring (1968). On April 1968 when Alexander Dubcek became the communist leader, there was a breakthrough in political and religious life. The reforms began were implemented covering all aspects of public life. The Church also conveyed its lost rights and asked for the restoration of religious life and the freedom of religious teachings. The Peace Movement of the Catholic Church by the State ceased. However, despite many external signs of democratization of public life, the process of rehabilitation of the Church progressed slowly. 
The hope for the continuation of the transformation of society ended by the entry of Warsaw Pact troops into Czechoslovakia (August 1968). After the troops invaded Czechoslovakia, the normalization took place i.e. return to the conditions before January 1968 and hence the limitation of the freedom of religious life. Priest movements devoted to the regime were soon reinstated in the form of Pacem in Terris (successor to the organization of the Peace Movement of the Catholic Church). In the 1980's, the hands-off approach in the Soviet Union's relations with its European satellite states, culminated in the liberation of Communist governments in the Eastern bloc (in November 1989 in Czechoslovakia), thus restoring religious and civil liberties.

\section{The Sites of Fatima and Levoča: The context}

\section{The Site of Fatima}

Fatima is a city-sanctuary located in the central region of Portugal. According to figures released by the Shrine, the site annually attracts over five million pilgrims arriving from all over the world (Papa Francisco - Fatima 2017). The history of the shrine began with the apparitions of the Virgin who took the appearance of "Our Lady of the Rosary" to three poor local children shepherding in the surrounding countryside of their village of Fatima. All six apparitions occurred between 13th May and 13th October of 1917, being officially recognised and receiving Church endorsement in 1930. "Our Lady of the Rosary" called for much prayer and the consecration of Russia to her name. The messages were used by the Portuguese dictatorship: Catholicism as one of the prime causes for the nation's historical development and also for the fight against communism.

Following the divine manifestation, a small chapel was built in 1919 and, a decade later, construction work began on the basilica, consecrated in 1953 (Image 2). In the new millennium, in 2007, the Church of the Holy Trinity was inaugurated with a seating capacity of 8,663.

In a completely deserted area, with the 1917 apparitions thousands of pilgrims began arriving in Fatima. Lodging was provided by itinerant sellers and food and drink stands that would often have beds for rental, supplemented by the letting of space in straw barns and storerooms (Ambrósio, 2000).

Although the territorial development was in great part due to the Church and economic agents it would not have been so successful without the strong support provided during the dictatorial regime (1928-1974) and the continued support during the democratic system since 1974. Already in 1928 (around two years before the apparitions had received Church approval), the minister of Public Works and Communications nominated a commission "to study an urbanisation plan for the site of Cova da Iria (Fatima) and propose the measures necessary for the defence, protection and exaltation of the place" (Oliveira, 1990: 15). In 1936, the Bishop of Leiria, met with the Minister of Public Works, with the latter committing himself to the prioritization of the project that led to the appointment of a famous architect to design the shrine and the surrounding areas. The plan was approved in 1948 and it was seen as "a decisive step towards the organisation of an urban agglomerate and established the terms of intervention of the Ministry of Public Works in terms of access routes, land-based regulations and the provision of technical assistance for the management of the Sanctuary of Fatima" (Oliveira, 1990: 25).

\section{Image 2: Shrine of Fatima}

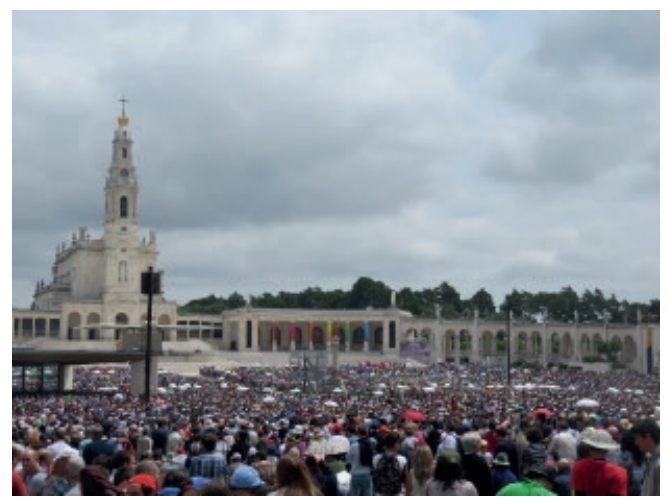

Source: Authors 
Due to the growing number of visitors and buildings in Fatima, the government ratified a new Development Plan in 1959 which was not restricted to the Sanctuary protection zone (130ha), but was rather extended to cover a wider geographical area (total of 380ha). That area became essential for pilgrimage lodging facilities, parking and the circulation of vehicles, religious constructions, residence zone designed for the temporary and permanent populations as well as the construction of public buildings. Infrastructure was developed to attract more visitors to Fatima.

News of the visit of Pope Paul VI to Fatima in 1967 led the ecclesiastical authorities to request that the government support the necessary construction of lodging and food establishments for an appropriate reception and hosting of millions of pilgrims expected. The government placed outmost importance in the "fiftieth anniversary commemorations not only for the projection they would have worldwide, irrespective of their religious aspect, but also due to their reflection on the scale of national tourism, given the exceptional number of foreign visitors who would certainly be visiting the country" (Oliveira, 1990: 68).

Recognition of the sheer profit made by the presence of around three million pilgrims in 1967 boosted the demand for further construction. By 1973, the local population had more than doubled and there were various hostels, four hotels, one motel, and many religious institutions providing lodgement (Ambrósio, 2006). So began the commodification of tourism in Fatima.

Even with the Revolution taking place in 1974, ending the dictatorship, in the same year the Urbanisation Services ordered that a property and land survey be conducted to review and expand the intervention scope of the urbanisation plan. In 1982, the visit by Pope John Paul II brought record number of pilgrims convincing the ecclesiastic and government authorities that the existing infrastructure was insufficient to accommodate the increasing number of visitors and that the urbanisation plan needed adjustments.

In 1987, the Presidency of the Council of Ministers, through Resolution no. 43/87, founded the Urban Coordination Office of Fatima. The introduction stated, "despite its manifest religious and tourism relevance, Fatima has not yet been endowed with the conditions, whether in terms of infrastructures or equipment, enabling it to effectively respond to the existing demand and which is estimated would rise with an increase in ease of access resulting from the construction of the Lisbon to Oporto motorway".

The visit of Pope John Paul II would be repeated in 1991 on the tenth anniversary of his assassination attempt. He would make still another visit to Fatima in 2000 with this third occasion serving for the beatification of Francisco and Jacinta, brother and sister who along with their cousin Lucia witnessed the three apparitions of the Angel of Peace in 1916 and several apparitions of the Blessed Virgin Mary at Cova da Iria in 1917. Fatima received further global recognition with visits by Pope Benedict XVI in 2010 and by Pope Francis I in 2017. The latter, for the 100th anniversary of the Marian apparitions announcing during the visit the canonization of Francisco and Jacinta.

In about 45 years (since the beginning of the democratic regime), the local population of Fatima more than doubled again (nowadays about 12.000 inhabitants), the hotels grew in both quantity and quality - from about 1.900 beds to about 7.000 beds. From no four-star hotels to thirteen four-star hotels - being the lodgment capacity complemented by about 8.000 beds in local accommodation and religious institutions. Nowadays Fatima, with its over 15,000 beds, holds the largest hotel capacity in the central region of Portugal.

Along its 100 years of existence, Fatima consolidated its international projection becoming one of the world's most well-known Catholic Marian shrines and a prominent religious tourism destination. Of the nearly 10 million visitors to religious heritage sites in Portugal, about 7 million are to Fatima. An overwhelming majority are Portuguese.

\section{The site of Levoča}

Levoča is an important historical town in eastern Slovakia, with rich history and invaluable art and historical monuments from the Middle Ages and the Mariánska hora (Marian Hill) - one of the most important pilgrimage sites in Slovakia. The first church was built here in the year 1247 in connection with the appreciation of the population for surviving the Tatar invasions. The beginning of the Marian pilgrimage on the Levoča hill is associated with the arrival of minorities in Levoča, who founded the monastery in the 14th century. The Jesuits who placed a statue of Our Lady on a hill over the Mariánska hora continued the Marian tradition. Several thousand people took part in the pilgrimage in this period, leading to the enlargement and rebuilding of the church in 1470. In the 15th century, took place the Feast of the Visitation of the Virgin Mary (a tradition that has taken place ever since). In the following 
years, the development phase of Levoča changed as a rich medieval town with many privileges and Mariánska hora as a pilgrimage site, where the visit reached approximately 30.000 believers.

The pilgrimages to the Mariánska hora continued during the 19th and early 20th of centuries. In 1820, a reconstruction of the church took place, chapel for Greek-Catholic believers built in 1843 and linden alley planted along the road to Mariánska hora. Between 1903 and 1914, a new neo-gothic church was built (Image 3) prompting increasing number of pilgrims. In 1945 came to Levoča, to thank for the cataclysm of the Second World War, more than 100.000 pilgrims and in 1947 up to 130.000 pilgrims.

With the political changes in 1948, religious persecution became increasingly evident and the pilgrimage did not even take place at all. For the next twenty years, there was significant restriction on the pilgrimage. From the point of view of the socialist State, Levoča as a pilgrimage place was the center of the anti-state reaction. Pilgrims were heavily controlled by the Communist regime and the priests required permission to perform the worship or confession. The State aimed to deny and devalue the pilgrimage, reduce the number of pilgrims, especially the number of young people and weaken the church's activities. There was even an attempt to get Mariánska hora under the authority of the army. This was the State's way of destroying the pilgrimage place. Furthermore, to the pilgrimage site, cultural, sporting and entertaining events were organized to discourage people from making the pilgrimage. Gradually, according to Dlugoš (2000), the number of pilgrims declines from 15.000 (1950) to 8.000 (1953).

\section{Image 3: Shrine of Mariánska hora}

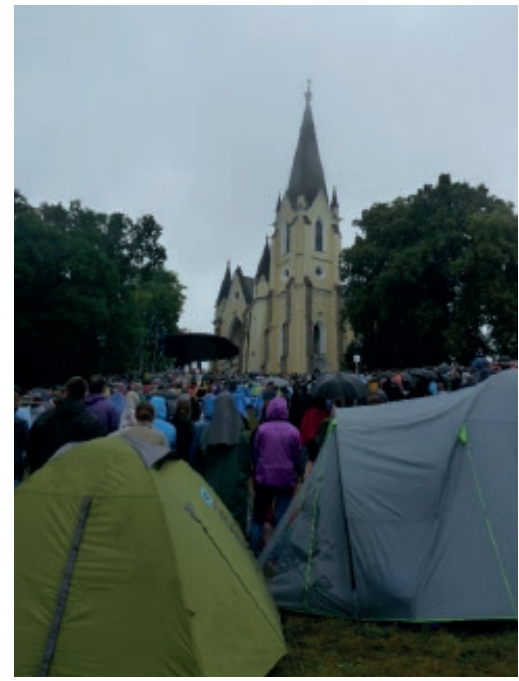

Source: Authors

In 1960, Levoča lost the position of the leading district town, which stopped its development completely. The town was failing economically mostly because no link had been established to the railway system. As industry was not developing, a significant part of the population left the town for lack of job opportunities. This intimidation intensified the friction between the People and the State. During this time of suffering, the people looked for charismatic leadership, be it individual or institutional. Increasingly, people turned to the Church for guidance in the pursuit of improving their meager means of survival.

The Prague Spring in 1968, prompting the visit of more than 150.000 pilgrims and in 1969 over 350.000 in 1969. Consequently, the church was equipped with electricity, painted and acquitted a paved exterior.

But in 1970, the political situation in Slovakia changed again and the pilgrimages returned to requiring the consent of the State. Private and public buses were prohibited to transport pilgrims and cars were not allowed to go directly to Levoča. They were diverted to the surrounding towns, even their registration details were taken, and then personal visits were conducted to private homes by the secret police. Drivers threatened pilgrims walking on the side of roads. There were no refreshment stands, drinking water not available and the pilgrims could not take food supplies to the Mariánska hora. 
Neither would doctors provide medical assistance to pilgrims. Entertainment (part of local festivities) was prohibited. Due to such obstacles, the number of pilgrims again dropped significantly to 80.000.

During this period, all requests for church renovation were rejected by the State. The post-war plans for construction of a new complex of monastery and church with a capacity for ten thousand people were unrealized, as well as the construction of roads. Little was achieved in the development of support infrastructure, particularly accommodation units, with only two available units and very few beds.

However, a new revival took place in the 1980's. In 1984, over 150.000 pilgrims attended the pilgrimage and its culmination was the public announcement and decree on the promotion of the church to Basilica minor by the Pope John Paul II, despite the efforts and threats of the regime to prevent it from happening. In the next few years, more than 250.000 people would visit Mariánska hora annually.

With the collapse of Communism in 1989, both political and civil activities were revived, freedom of press restored, gathering and undisturbed religious practices were restored and the church underwent renovation work. Moreover, in 1990 over 500.000 pilgrims took part on the Levoča pilgrimage. An extraordinary pilgrimage followed in 1991 with 600.000 participants and many Slovak and foreign cardinals and bishops, which meant that the pilgrimage place of Mariánska hora shifted from a regional dimension and becomes a European pilgrimage place. The most numerous pilgrimage in the history of Mariánska hora was in 1995, linked with a visit by Pope John Paul II. The attendance recorded was 650.000 pilgrims. In the following years, the number of pilgrims on Mariánska hora stabilized during the main pilgrimage to between 400.000 and 500.000 .

Meanwhile, certain improvements were made in Mariánska hora. The city financed the lighting alongside the path leading to the Mariánska hora and was introduced a telephone line. The outer altar was built with donations from believers. Despite the long history, the water pipeline, canalization and social-sanitary facilities were built only in 1991. In the following years, two asphalt access roads and a pilgrimage house were built. Development and construction of support infrastructure took place in Levoča, with new restaurants and hotels opening. In 2009, Levoča was added to the UNESCO World Heritage List. The church underwent further renovation as well as the surrounding landscaping. The city expanded and diversified its tourist infrastructure (hotels, restaurants, information offices, etc.) and currently offers 941 beds.

\section{Conclusions and future research}

\section{Conclusions}

In Portugal, during the fascist dictatorship (1928-1974), religion was an ideological instrument. The Government used it for dominating all social classes, especially the most disadvantaged. In this sense, the Clergy's role was of vital importance; many priests used the religious creed as a way to rule the souls/the citizens, often with the purpose that they would not revolt against their precarious conditions of life. The dictator Salazar as a leitmotiv for his policies adopted the motto God-Homeland-Family. Within the hierarchical established corporate order was reserved a particular place to each one being one of its appanages the "honest poverty" promoted by the Portuguese Catholic Church, still practiced today. It is still common to hear people on rural areas say "I am poor, but honest".

This propaganda was possible and convenient given the substantial differences in social and political structures in the North and the South of the country. The North, characterized by primary small and medium land-holdings, non-cooperative agricultural enterprises which are not conducive to the development of class-consciousness or class-based movements and heavily dominated by the Catholic Church (Leeds, 1977). The Concordat between the Holy See and the Portuguese Republic of 1940, and signed several more times since then, permitted the control of the densely populated North through the Church and the regime to concentrate its efforts on the more unstable and class-conscious South. The regime placed emphasis on the protection of the landed aristocracy and a mercantilist bourgeoisie (1925-1959) and the interests of the growing industrial bourgeoisie in the later years (1950-1974) in an attempt to control carefully the pace of economic and industrial growth so as to prevent the formation of a potentially disruptive urban proletariat or a new technocratic middle class (Leeds, 1977). Some would argue that, had the apparitions in Fatima taken place a bit further south in the country, the impact would have been completely different and the regime may not have endured as long as it did.

In Slovakia, during the communist dictatorship (1948-1989), according to the socialist theories, religion was considered peoples' opium. The Government's policies to dominate society was based in a hierarchical laic system in which Church had no place. In fact, during that period, the rulers were 
against participation in pilgrimages and worshippers were persecuted/discriminated in their jobs/ professions (mainly teachers/academics). Although pilgrimages still took place (but monitored by the secret police), the regime restricted the number of priests and means of transport. Simultaneously, other actions were enticed to discourage people from attending religious events.

In both countries, religion had different developments with the transition to democratic regimes. In Portugal, democracy contributed to the growth of religious tourism, mainly in the best well-known Portuguese shrine - Fatima. In Slovakia, democracy allowed religious beliefs and doctrines to be freely professed and in the last two decades, some of the early popular shrines, such as Levoča, have witnessed growth in the number of pilgrims. While the left wing regime did everything possible to eradicate religion and promote atheism, the right wing regime embraced Catholicism but managed to indoctrinate it into a nationalistic frame of mind through education and other forms of control through the hierarchy of the Church.

In Fatima, religious tourism developed regardless of the political regime, being established synergies between the Church, economic agents and governmental and local authorities. In Levoča, significant development in religious tourism practically began only in the era of democratization. Despite the religious freedom restored by the democratic regime and the increase in number of pilgrims (mostly concentrated in the first weekend of July) one cannot yet consider that religious tourism plays an important role in the Levoča regional economy. For turning it into a reality, it is necessary that the three main actors in the process (Church, private economic agents and local administration) work together to improve on the synergies and the respective structures for positioning Mariánska hora in the list of the main Catholic Marian shrines.

Different types of sites obviously have different visitor potential (Ejstrud, 2006). The focus of this study was on determining the two approaches taken at two different places of emotion and religious sites, in two different countries, encompassing authoritarian and democratic regimes and how the two sites have evolved as tourist destinations. It was identified the need to monitor changes in attitude and behaviour as regards to religion (in general) and pilgrimage sites (in particular) to contribute to better planning. Indeed, we should never forget how history shows us that in the cycles of destruction, it is the highest profile sites the first to succumb.

\section{Future research}

The value of this study is in analysing how changes in policies can bring many modifications in the way religion and religious sites are accepted by different political doctrines and regimes. However, the comparative case studies of Fatima and Levoča suggest that more knowledge is needed on infrastructure development at iconic religious and pilgrimage sites in order to establish its suitability to current and potential visitor needs. This would provide more insight into factors, which could facilitate the involvement of local stakeholders (public or private) in its management and dynamics, to allow an understanding of both tangible and intangible elements and identify needs and actions to be implemented.

\section{Acknowledgment}

The content of this research article emerges from the research grant provided by the Research and Development Agency (FCT) of Portugal and the Research and Development Agency of Slovakia, under the contract No. SK-PT-2015-0011.

\section{Bibliography}

Ambrósio, V. 2006. O Turismo Religioso - Desenvolvimento das Cidades Santuário, unpublished PhD thesis, Lisboa, Faculdade de Ciências Sociais e Humanas da Universidade Nova de Lisboa.

Cipriani, R. 2009. Religions in Europe, Religion, Vol. 39: 109-116.

Cosgel, M. \& Miceli, T. 2009. State and Religion, Journal of Comparative Economics, Vol. 37: 402-416. da Mota, F. 2017. O papa do dia a dia. Jornal de Noticias, 11/05/2017, p. 11.

Deutsch, K. W. 1961. Social Mobilization and Political Development, American Political Science Review, Vol. 55(3): 493-514. 
Dlugoš, F. 2000. Dejiny Mariánskej hory v Levoči [History of Mariánska hora, in Levoča]. Levoča: Polypress.

Dubovský, J. 1998. Akcia kláštory [Monastry Action]. Martin: Matica slovenská.

Ecclesia 2004. A Concordata de 2004 [online] Available at:. http://www.agencia.ecclesia.pt/portal/a-concordata-de-2004/ [Accessed 20 Jan. 2019]

Ejstrud, B. 2006. Visitor numbers and feasibility studies. Predicting visitor numbers to Danish open-air museums using GIS and Multivariate statistics, Scandinavian Journal of Hospitality and Tourism, Vol. 6 (4): 327-335.

Freire, P. 1972. Cultural action for freedom. Harmondsworth, Middlesex: Penguin.

Grigordiadis, T. 2016. Religious origins of democracy \& dictatorship, Journal of Policy Modeling, Vol. 38:785-809.

Halko, J. 2004. Agenti za spovednou mriežkou. Lož ako pracovná metóda socialistického režimu / Hal'ko, Jozef. 4, História revue 4, č. 3-4, s. 17-19.

Halkko, J. 2012. Vybrané kapitoly z cirkevných dejin [Selected captures of Church history]. Bratislava: Rímskokatolícka cyrilometodská bohoslovecká fakulta, Comenius University.

Heidi, M. \& Gronhaug, K. 2006. Atmosphere. Conceptual Issues and Implications for Hospitality Management, Scandinavian Journal of Hospitality and Tourism, Vol. 6(4): 271-286.

Huntington, S. 1968. Political Order in Changing Societies. New Haven: Yale University Press.

Huntington, S. 1991. The Third Wave: democratization in the Late Twentieth Century. London: University of Oklahoma Press.

Leeds, E. 1977. Solutions to dislocation in the case of Portugal; emigration vs mobilization, Society for Spanish and Portuguese Historical Studies, Vol. III, N. ${ }^{\circ}$ 8-9: 278.

Leitão, I. 2004. Antero de Quental e Miguel de Unamuno - As Imortais Contradições. Barcelona, unpublished PhD thesis, Barcelona, Departamento de Filología Española de la Universidad de Barcelona.

Lerner, M. 1986. Surplus Powerlessness: The Psychodynamics of Everyday Life and the Psychology of Individual and Social Transformation. Oakland: Institute for Labor and Mental Health.

Lindbloom, C. 1977. Politics and Markets: The World's Political Economic Systems. New York: Basic books, Inc. Publishers,

Linz, J.J. \& Stepan, A. 1996. Problems of democratic transition and consolidation: Southern Europe, South America and post-Communist Europe. Baltimore: Johns Hopkins University Press.

Mikloško, F. 2009. Tri dvadsat'ročia cirkvi na Slovensku. Impulz, Vol 5, No 3 in http://www.impulzrevue. sk/article.php?460, [Accessed 10 Oct. 2017].

Necula, G. 2012. Religious Terminology Facing Communist Ideology, Procedia-Social and Behavioral Sciences, Vol. 63:49-57.

Norenzayan, A. \& Shariff, A.F. 2008. The origin and evolution of religious prosociality, Science, Vol. 322 (5898):58-62.

Northmore-Ball, K. \& Evans, G. 2016. Secularization versus religious revival in Eastern Europe: Church institutional resilience, state repression and divergent paths, Social Science Review, Vol. 57: 31-48

Oliveira, F. 1990. Fátima. Vila Nova de Ourém: Câmara Municipal.

Orth, M. 2015. The world's most powerful woman, National Geographic, December 2015: 32-59.

Papa Francisco - Fátima 2017 (2017) Fátima 2016 [online] Available at: http://www.papa2017.fatima. pt/pt/pages/fatima-2016 [Accessed 30 Sep. 2017].

Paxton, R. O. 2004. The Anatomy of Fascism. London: Allen Lane.

Payne, S.G. 1995. A History of Fascism, 1914-1945. Madison: University of Wisconsin Press.

Pešek, J. 2000. Štát a katolícka cirkev na začiatku komunistickej totality [State and catholic church at the beginning of communistic dictatorship]. In J. Halko (Ed.), 50 rokov od 50-tych rokov. Paper presented at coloqium about church persecution at the beginning of communistic regime, Bratislava: Comenius University in Bratislava, 2 May (pp. 59-71).

Petruf, P. \& Sikora, S. 2007. Od ludovej demokracie po pád komunistického režimu. In M. Londák, \& V. Jaksicová (Eds.), Dejiny Slovenska: dátumy, udalosti, osobnosti. [Slovakia history: dates, occasions, personality]. Bratislava: SLOVART (pp. 472-679).

Renner, H., Samson, I. 1993. Dejiny Československa po roku 1945. [Chechoslovakia history after 1945]. Bratislava: Slovak academic press.

Robbers, G. 2001. Church and State, Institute for European Constitutional Law, University of Trier, Trier, Germany.

Rosas, F. (Ed.) 1998. Portugal no fim do milénio. Actas do colóquio internacional. Lisboa: Fim de Século. Simpson, D. 2014. A Igreja Católica e o Estado Novo Salazarista. Edições 70. Lisboa 
Smith, A. E. 2017. Democratic Talk in Church: Religion and Political Socialization in the Context of Urban Inequality, World Development http://dx.doi.org/10.1016/j.worlddev.2017.05.032 [Accessed 30 Sep. 2017]

Unger, R. 1987. False Necessity: Anti Necessitarian Social Theory in the Service of Radical Democracy. Cambridge: Cambridge University Press.

Wald, K.D., Owen, D.E. \& Hill, S.S. 1988. Churches as political communities, American Political Science Review, Vol. 82 (2): 531-548. 